\title{
Zinc Biofortification in Food Crops Could Alleviate the Zinc Malnutrition in Human Health
}

\author{
Subhashisa Praharaj ${ }^{1}$, Milan Skalicky ${ }^{2, * \mathbb{D}}$, Sagar Maitra ${ }^{1} \mathbb{D}$, Preetha Bhadra $^{3}$, Tanmoy Shankar ${ }^{1} \mathbb{D}$, \\ Marian Brestic ${ }^{2,4}$ (D), Vaclav Hejnak ${ }^{2}$ (D) Pavla Vachova ${ }^{2}$ and Akbar Hossain ${ }^{5, *(D)}$
}

1 Department of Agronomy, Centurion University of Technology and Management, Pralakhemundi 761211, India; subhashisa.praharaj@cutm.ac.in (S.P.); sagar.maitra@cutm.ac.in (S.M.); tanmoy@cutm.ac.in (T.S.)

2 Department of Botany and Plant Physiology, Faculty of Agrobiology, Food, and Natural Resources, Czech University of Life Sciences Prague, Kamycka 129, 16500 Prague, Czech Republic; marian.brestic@uniag.sk (M.B.); hejnak@af.czu.cz (V.H.); vachovap@af.czu.cz (P.V.)

3 Department of Biotechnology, Centurion University of Technology and Management, Pralakhemundi 761211, India; preetha.bhadra@cutm.ac.in

4 Department of Plant Physiology, Slovak University of Agriculture, Nitra, Tr. A. Hlinku 2, 94901 Nitra, Slovakia

5 Department of Agronomy, Bangladesh Wheat and Maize Research Institute, Dinajpur 5200, Bangladesh

* Correspondence: skalicky@af.czu.cz (M.S.); akbarhossainwrc@gmail.com (A.H.)

\section{check for} updates

Citation: Praharaj, S.; Skalicky, M.; Maitra, S.; Bhadra, P.; Shankar, T.; Brestic, M.; Hejnak, V.; Vachova, P.; Hossain, A. Zinc Biofortification in Food Crops Could Alleviate the Zinc Malnutrition in Human Health. Molecules 2021, 26, 3509. https:// doi.org/10.3390/molecules26123509

Academic Editors: Ryszard

Amarowicz, Adriano Costa de Camargo and Marcello Iriti

Received: 21 April 2021

Accepted: 4 June 2021

Published: 9 June 2021

Publisher's Note: MDPI stays neutral with regard to jurisdictional claims in published maps and institutional affiliations.

Copyright: (c) 2021 by the authors. Licensee MDPI, Basel, Switzerland. This article is an open access article distributed under the terms and conditions of the Creative Commons Attribution (CC BY) license (https:// creativecommons.org/licenses/by/ $4.0 /)$.
Abstract: Micronutrient malnutrition is a global health issue and needs immediate attention. Over two billion people across the globe suffer from micronutrient malnutrition. The widespread zinc (Zn) deficiency in soils, poor zinc intake by humans in their diet, low bioavailability, and health consequences has led the research community to think of an economic as well as sustainable strategy for the alleviation of zinc deficiency. Strategies like fortification and diet supplements, though effective, are not economical and most people in low-income countries cannot afford them, and they are the most vulnerable to $\mathrm{Zn}$ deficiency. In this regard, the biofortification of staple food crops with $\mathrm{Zn}$ has been considered a useful strategy. An agronomic biofortification approach that uses crop fertilization with $\mathrm{Zn}$-based fertilizers at the appropriate time to ensure grain Zn enrichment has been found to be cost-effective, easy to practice, and efficient. Genetic biofortification, though time-consuming, is also highly effective. Moreover, a Zn-rich genotype once developed can also be used for many years without any recurring cost. Hence, both agronomic and genetic biofortification can be a very useful tool in alleviating $\mathrm{Zn}$ deficiency.

Keywords: agronomic biofortification; genetic biofortification; malnutrition; micronutrient; zinc

\section{Introduction}

Food and nutritional security are key to human health. Food insecurity, imbalanced diet, consumption of food grains with poor nutritional quality, lack of dietary diversity, etc. negatively affect human health [1,2]. In fact, food and nutritional insecurity may further deteriorate diet quality; thus, increasing the danger of undernutrition as well as obesity [3]. The increase in the cultivation of cereal crops and cash crops in the intensive cropping systems have caused a reduction of diversity in the diet as well as micronutrient uptake [4]. This is especially true in rural areas of developing countries, where the human diet is largely based on cereal. The green revolution era that introduced input responsive and high yielding varieties of some fine cereals like wheat and rice made agriculture profitable for farmers. This led the farmers to grow highly productive and economically rewarding cereal crops, with a simultaneous decrease in the area growing pulses [4]. The low dietary diversity is evident from the fact that, out of 7000 species ever cultivated by humans, just 30 species provide around 95\% of the world energy supply [4,5]. As food and nutritional security is still a distant dream, especially in many developing countries, finding a solution to assure food and nutritional security is a prime concern. If the current trend lasts, the number of people affected by hunger would surpass 840 million by 2030, against the target 
of achieving Zero Hunger by 2030 [3]. Economic disparity plays an important role in dietary habit.

Low-income countries largely trust staple foods while relying less on fruits, vegetables, and foods from animal sources compared to high-income countries. Micronutrient malnutrition, due to a lack of sufficient micronutrients in the diet results in serious but often invisible health consequences, referred to as hidden hunger. In the world, over 2 billion people are affected by micronutrient deficiency $[6,7]$. This micronutrient malnutrition can be attributed to consumption of a diet having low micronutrient content and low dietary diversity. Hidden hunger can be addressed through a nutrition-specific and nutritionsensitive approaches [8]. The nutrition-specific approach or direct approach involves dietary interventions, i.e., consuming a more diversified diet, micronutrient supplements, and fortification. The nutrient-sensitive approach, on the other hand, involves the biofortification approach (Figure 1) [9]. Biofortification refers to the process of increasing the concentration and/or bioavailability of nutrients in the edible part of plants. Enhancing micronutrient concentration in the staples can be a sustainable and cost-effective intervention in improving the micronutrient uptake by people [10-13]. The most common source of food among people, especially in low incoming countries are cereal-based diets [14,15]; therefore, enriching them with micronutrients can improve micronutrient consumption. Staple food grains like wheat, rice, maize, etc. are consumed by a large number of people across the globe, when they are biofortified with $\mathrm{Zn}$ it could have a great impact in reducing hidden hunger.

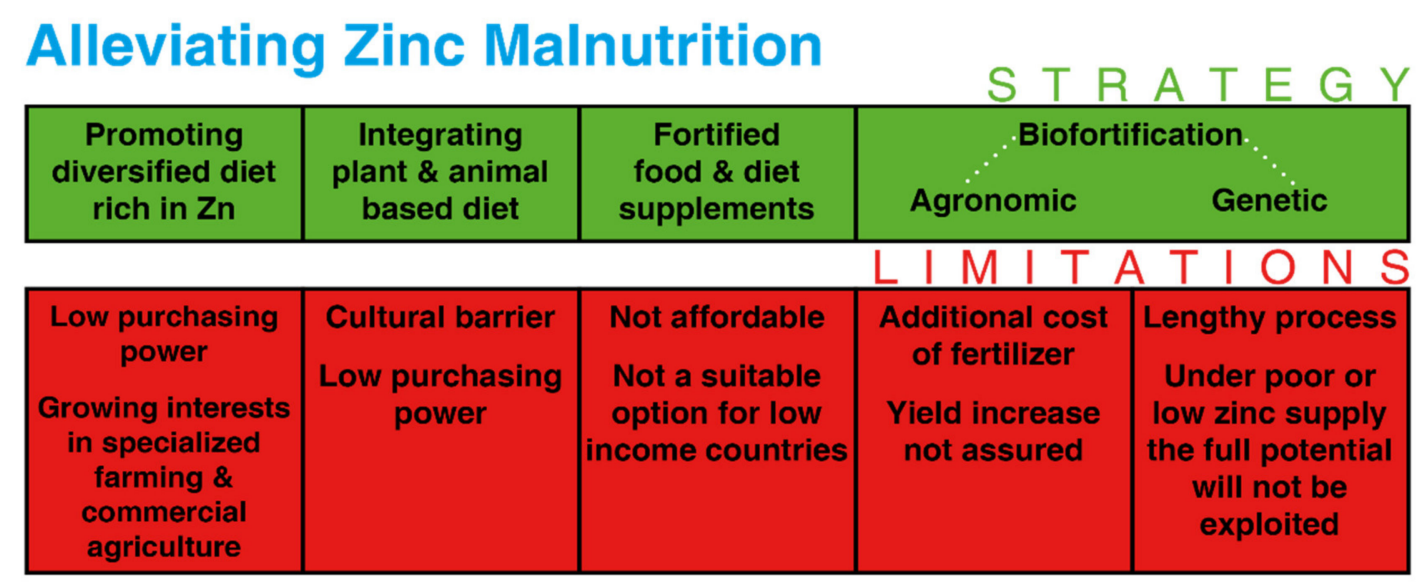

Figure 1. Different strategies for alleviating Zn deficiency.

Amongst different micronutrients, $\mathrm{Zn}$ inadequacy is common in both plants and animals $[11,16]$. Zn deficiency is considered an important risk factor for human health causing death [11,17]. Around $60-70 \%$ of the population in Asia and Sub-Saharan Africa could be vulnerable to low Zn uptake [18]. A third of the world's population is at the risk of Zn deficiency, which is more predominant among children under the age of five, as they require more $\mathrm{Zn}$ to meet growth and developmental needs $[15,19]$. Zn deficiency is associated with several problems in human health, e.g., poor physical growth, weakened immunity system, DNA damage, cancer, increased risk of infections, poor birth outcomes in pregnant women, etc. [11,15,20-22]. The epidermal, nervous, gastrointestinal, skeletal, immune, and reproductive systems are the organs most affected clinically by Zn deficiency [23].

From the discussion above, it is very clear that a healthy diet can not only improve human health and maximize human resource potential. It can also reduce the costs related to health. We need suitable intervention like biofortification to make nutritionally superior food available to every person in the world at an affordable cost. In this direction, biofortification of staple food grains like rice, wheat, and maize with zinc and their inclusion in the human diet can help in alleviating zinc malnutrition. 


\section{Role of $\mathrm{Zn}$ in Human Health}

$\mathrm{Zn}$ is a very crucial nutrient for maintaining optimal human health. The essentiality of $\mathrm{Zn}$ for human was established in the year 1961 [23]. Around 2800-3000 proteins in the human body contain $\mathrm{Zn}$ prosthetic groups $[15,18,24]$. $\mathrm{Zn}$ is also required for the function of over 300 enzymes [25]. It is also interesting that $\mathrm{Zn}$ is involved in all six classes of enzyme, i.e., hydrolases, lyases, ligases, isomerases, oxidoreductases, and transferases [26]. Zn plays a vital role in the overall physical growth, development, immune function, reproductive health, and neurobehavioral activity. Considering the diverse and very significant roles of $\mathrm{Zn}$ in human health, it can be safely assumed that $\mathrm{Zn}$ nutrition is of utmost importance for human health. As Zn performs multifaceted roles in the human body, various physiological signs are found in response to $\mathrm{Zn}$ deficiency. The response to $\mathrm{Zn}$ deficiency may vary depending on the extent/severity of the deficiency. The negative impact and clinical effect of Zn deficiency may vary with age; diarrhoea is the most common symptom in early infancy [23]. Skin related problems, recurrent infections, and dwarfing are common among toddlers or school-aged children $[18,23,27]$. The manifestation of $\mathrm{Zn}$ deficiency among adults includes recurrent infections, hypogeusia, chronic non-healing leg ulcers, and adverse pregnancy outcomes $[18,23]$.

Though the mechanism of $\mathrm{Zn}$ deficiency-induced impairment of growth and development is not clearly understood, it is one of the most studied effects of $Z n$ deficiency. The effect of $Z n$ deficiency is more significant especially in the time of rapid growth like infancy, puberty, and pregnancy [23]. Intake of a supplementary dose of $\mathrm{Zn}$ was found to minimize the risk of malaria [28], pneumonia [29], and diarrhoea [23,29].

Considering the importance of $\mathrm{Zn}$ in human health (Table 1 ), there is a growing interest in improving $\mathrm{Zn}$ nutrition. Strategies are being made to improve $\mathrm{Zn}$ intake among humans to improve the bioavailability of the $\mathrm{Zn}$ [30-32]. Bioavailability refers to the fraction of $\mathrm{Zn}$ intake that can be absorbed in the human gut [33]. Thus, not only Zn intake but also its bioavailability should be given equal importance for improving Zn nutrition $[7,11]$. The bioavailability of $\mathrm{Zn}$ can be improved by reducing the anti-nutrition factor-like phytate in the grain [15]. The people in developing countries where the diet is dominated by cereals are subjected to micronutrient malnutrition disproportionately, since cereals are not only a poor source of micronutrients but also the high content of phytate in cereals reduces the bioavailability of Zn further [33,34].

Table 1. Role of $\mathrm{Zn}$ in different organ systems.

\begin{tabular}{|c|c|c|}
\hline Organ Systems & Role of $\mathrm{Zn}$ & References \\
\hline Cardiovascular & $\begin{array}{c}\text { A cardioprotective role, reduces risk of heart failure, and an important role in } \\
\text { cardiovascular health }\end{array}$ & {$[35,36]$} \\
\hline Integumentary system & Skin health, wound healing, protection against UV radiation, and acts as antioxidant & [37-40] \\
\hline Reproductive system & $\begin{array}{l}\text { An important role in formation and maturation of spermatozoa, for ovulation and } \\
\text { fertilization; functioning of the male and female reproductive system }\end{array}$ & [41-43] \\
\hline Nervous system & $\begin{array}{l}\text { The modulator of neuronal excitability, an important role in neuronal metabolism, and } \\
\text { the modulator of synaptic activity and neuronal plasticity }\end{array}$ & {$[44,45]$} \\
\hline Respiratory system & $\begin{array}{c}\text { Reduces the incidence of acute lower respiratory infection; low Zn may increase the risk } \\
\text { of pneumonia in elderly }\end{array}$ & {$[46,47]$} \\
\hline Endocrine system & Thyroid hormone metabolism, structure, and activity of insulin. & [43] \\
\hline
\end{tabular}

\section{Role of $\mathrm{Zn}$ in Crop}

$\mathrm{Zn}$ is an essential plant nutrient and known as a micronutrient because of its low requirement. $\mathrm{Zn}$ remains in plants in either free ionic form or as a complex with many low molecular weight compounds [48]. Though the requirement of $\mathrm{Zn}$ in plants is low, it plays an important role in overall plant growth and development [33]. Zn is essential for different biochemical processes including auxin metabolism [48], chlorophyll synthesis [33], and activation of different enzymes. $\mathrm{Zn}$ is also involved in carbohydrate [48], lipid, and nucleic acid metabolism [7]. 
$\mathrm{Zn}$ is a constituent of many important enzymes of great significance such as carbonic anhydrase, alcohol dehydrogenase, and superoxide dismutase [33,49]. Carbonic anhydrase facilitates photosynthetic carbon dioxide fixation [48]. This may be one of the reasons why photosynthesis is inhibited under acute Zn deficiency. Alcohol dehydrogenase performs a vital job in flooding tolerance of crops [50,51]. Superoxide dismutase helps in the detoxification of superoxide radicals and protects the lipids and proteins of the membrane against oxidation $[52,53]$. Lack of sufficient $\mathrm{Zn}$ in the plant may damage the membrane integrity and increases membrane leakiness.

$\mathrm{Zn}$ is also an integral part of the $\mathrm{Zn}$ finger family of transcription factors that controls cell proliferation and differentiation [33]. Zn plays a vital role in chloroplast function and development, where Zn dependent SPP peptidase activity and Photosystem II repairing are very crucial $[33,54]$. Zn deficiency causes a significant decline in the chlorophyll content and abnormality in chloroplast structure, thus negatively affecting photosynthesis in plants [48].

The possible role of $\mathrm{Zn}$ in water uptake and transport in plants and a short-term tolerance to heat and stress tolerance has been reported [55-59]. The function of $\mathrm{Zn}$ finger proteins in stress tolerance was reported by many researchers [60-63]. The role of $\mathrm{Zn}$ in plant defence against pathogens and herbivores have also been highlighted [64].

\section{Biofortification for Grain Zn Enrichment: The Concept}

Zn deficiency in crops limits crop yield and grain nutritional quality $[11,65]$. Cereal crops, which play a significant role in meeting the daily calorific need in developing countries, are usually low in $\mathrm{Zn}$ concentration [9,15]. The $\mathrm{Zn}$ concentration in cereals is found to be even lower when the crop is grown in soil with low $\mathrm{Zn}$ content [11]. The regions having low soil $\mathrm{Zn}$ concentration shows a prevalence of $\mathrm{Zn}$ deficiency among humans suggesting a strong interrelationship among soil-plant-human health [11]. The prevalence of high $\mathrm{Zn}$ deficiency in soils might be due to low addition of organic matter to soils, intensive agriculture that removes a huge amount of nutrient from the soil including micronutrients, and lower use of micronutrient fertilizers. Biofortification attempts to improve this soil-crop-human interrelationship in a way that can ultimately help to alleviate Zn deficiency in humans [9].

The biofortification approach aims at enriching the grains with minerals like iron, $\mathrm{Zn}$, selenium, iodine, etc., so that, their intake can be improved among people consuming those grains $[6,9,14]$. As micronutrient malnutrition or hidden hunger is more prevalent in low-income countries where consumers have low purchasing power, consequently they can hardly afford micronutrient supplements or a relatively healthier diet rich in micronutrients. Under such conditions, improving the nutrient status of the commonly consumed staple food grains gives the most sustainable option for alleviating micronutrient malnutrition $[11,34,66]$. An effective biofortification strategy should ensure that grain yield be improved or at least maintained, increase the grain $\mathrm{Zn}$ concentration for significant human health benefits, and the grain performance must be stable across environments [16,67]. As $\mathrm{Zn}$ deficiency is often associated with a cereal-based diet and because people in developing countries-especially in rural areas-are highly dependent on cerealbased diets due to reasons such as, poor purchasing power, cultural preference, and high food price, biofortification of cereal grains with $\mathrm{Zn}$ can be a sustainable solution to increase Zn intake [14,15].

Understanding the physiological basis of micronutrient accumulation in the grains is of utmost importance for successful biofortification. Micronutrient concentration in the edible portion of the crop is decided by nutrient availability to plants and the process of absorption, translocation, and redistribution of micronutrients in the plant, which are being regulated by homeostatic mechanisms that allow accumulation of micronutrients in an adequate amount, yet at a non-toxic level $[9,16]$. The absorption of nutrients by the plant depends on soil factors, e.g., the physicochemical and biological properties of soil, agronomic factors, or management factors, that decide micronutrient availability at rhizosphere and plant factors such as root morphology, root cell activities leading to 
increased micronutrient solubility and mobility $[10,18,48]$. All these factors are in a close and complex interaction with each other that decides micronutrient absorption by plants. The agronomic practices like organic matter addition, micronutrient fertilizer application, maintaining optimum soil moisture for facilitating $\mathrm{Zn}$ diffusion to plant roots can help in increasing micronutrient absorption by plant roots [18].

The crop also plays a very important role in the absorption of micronutrients. For enhancing Zn uptake, the micronutrient level in the root-soil interface should be increased. Changing root morphology for increasing the absorptive surface area can enhance $\mathrm{Zn}$ uptake. Efflux of $\mathrm{H}^{+}$from root cells and the release of metal complexing compounds and reductants can also be very useful root characteristics for increasing $\mathrm{Zn}$ uptake [16]. Understanding these traits can help in developing new Zn-efficient genotypes. After uptake, the micronutrient must be efficiently translocated and accumulated in the edible parts of the plant [9]. The micronutrients can be translocated either directly from the roots to the grains or they can be re-translocated from the vegetative tissues after the reproductive period $[9,11]$. The process of translocation and re-translocation, concerning different genotypes and environmental conditions, must be studied. The accumulated micronutrients should be bioavailable to give a favourable health outcome for the people consuming the biofortified food grains. Two approaches of biofortification, agronomic biofortification and genetic biofortification are discussed below:

\subsection{Agronomic Biofortification}

When the soil is inherently deficient in Zn content and/or the solubility of Zn in soils is low, then the plant cannot absorb sufficient $\mathrm{Zn}$ to meet its physiological or metabolic need. In fact, nearly $50 \%$ of cereal growing areas in the world have been found deficient in $\mathrm{Zn}$ [11]. This leads to low $\mathrm{Zn}$ concentration in the grains of crops grown in those soils. Under such a scenario, improving the availability of $\mathrm{Zn}$ to the crop can improve grain $\mathrm{Zn}$ concentration $[4,6,7,10]$. This simple approach of crop fertilization with Zn-based fertilizers, to improve grain $\mathrm{Zn}$ concentration, is termed agronomic biofortification. Application of Zn-based fertilizers to the crop shows different responses depending on the method of application (e.g., soil/foliar/seed priming or any combination of different methods), source of $\mathrm{Zn}$ applied time of $\mathrm{Zn}$ application, and also the genetic makeup of the crop and the environment in which the crop is grown $[7,15,17,18]$. Considering these large numbers of factors, which can potentially affect the efficacy of agronomic biofortification in improving grain $\mathrm{Zn}$ concentration, the source, time, method of application, and rate of application must be optimized to get the best possible result $[7,12,18]$.

Agronomic biofortification is cheap and provides the dual advantage of yield enhancement and improvement of grain $\mathrm{Zn}$ concentration. Though genetic biofortification also shows a lot of promise, developing a variety takes a lot of time and effort [11]. Moreover, the achievement of genetic biofortification may be jeopardized in the absence of sufficient $\mathrm{Zn}$ in the soil [11].

\subsubsection{Effect of Different Methods of Zn Application on Grain Zn Enrichment}

$\mathrm{Zn}$ is provided to the crops by soil application, foliar application, seed application (priming), or by a combination of these methods [68-72]. Different responses are found with different application methods. Each application method has certain advantages and limitations (Table 2). Soil application is usually the most commonly used method of soil application. The efficacy of soil-applied fertilizer largely depends on the soil environment $(\mathrm{pH}$, moisture content, presence of antagonist nutrients, etc.) and ability of plants to successfully absorb the nutrients whereas in the foliar application, the uptake and translocation of nutrients to the grain is largely dependent on the crop. Different crops show different responses to the $\mathrm{Zn}$ application methods. For example, among rice, wheat, and maize, the response of wheat (in terms of increase in grain $\mathrm{Zn}$ concentration) to foliar $\mathrm{Zn}$ application was highest, followed by rice and maize [15]. 
Table 2. Different $\mathrm{Zn}$ application methods, their advantages and limitations.

\begin{tabular}{|c|c|c|}
\hline Application Methods & Advantages & Limitations \\
\hline Soil Application & $\begin{array}{l}\text { Minimizes soil } \mathrm{Zn} \text { deficiency } \\
\text { The residual effect may benefit } \\
\text { subsequent crops }\end{array}$ & $\begin{array}{c}\text { High fertilizer requirement } \\
\text { Availability to plant may decrease due to adverse } \\
\text { soil properties }\end{array}$ \\
\hline Foliar application & $\begin{array}{l}\text { Lower fertilizer requirement } \\
\text { Not affected by adverse soil characteristics }\end{array}$ & $\begin{array}{l}\text { Crop requirement in the early seedling stage is not met } \\
\text { Very high dose of nutrient cannot be applied using the } \\
\text { foliar method }\end{array}$ \\
\hline Seed priming & $\begin{array}{l}\text { Lower fertilizer requirement } \\
\text { Suitable for stressed environments }\end{array}$ & $\begin{array}{l}\text { A higher amount of nutrient cannot be applied using this } \\
\text { method as a high concentration of priming solution may } \\
\text { negatively affect germination }\end{array}$ \\
\hline
\end{tabular}

\subsubsection{Soil Application}

The efficiency of soil-applied $\mathrm{Zn}$ fertilizer depends on soil $\mathrm{pH}$. The availability of $\mathrm{Zn}$ is relatively higher at acidic soil $\mathrm{pH}$. The solubility of soil decreases hundred-fold with each unit increase in $\mathrm{pH}$ [73]. Liming of acidic soils has been found to reduce the availability of $\mathrm{Zn}$ [18]. The $\mathrm{Zn}$ deficiency in calcareous soil can be attributed to a $\mathrm{CaCO}_{3}$ induced rise in $\mathrm{pH}$, direct sorption of $\mathrm{Zn}$ to the precipitated $\mathrm{CaCO}_{3}$, and formation of insoluble calcium Znate [22]. Alkaline soil, covering about 30\% of the global farmland, shows low $\mathrm{Zn}$ availability to plants $[15,74]$. Other than $\mathrm{pH}$, the other factors influencing $\mathrm{Zn}$ fixation are complexation with organic matter, occlusion in minerals, diffusion into micropores and interparticle space, solid-phase diffusion, and co-precipitation with other metals $[18,75,76]$.

As $\mathrm{Zn}$ reaches the plant root predominantly through diffusion [77], therefore low soil moisture and organic matter limits the process and thus plant $\mathrm{Zn}$ availability is reduced [11,15,78,79]. As limiting moisture condition and low organic matter is a common condition observed in agricultural fields, consequently such conditions are expected to reduce $\mathrm{Zn}$ uptake by plant roots [74,80]. Soil moisture plays an important role in soils with low Zn availability. The soil moisture acts as a medium for $\mathrm{Zn}$ transport from soil to root in the diffusion process. Hence, the negative impacts of $\mathrm{Zn}$ deficiency are more fatal under rainfed conditions than under irrigated condition [11]. The Zn availability to crops from soil-applied Zn may also be affected by its interaction with other nutrients. Positive $\mathrm{Zn}-$ nitrogen interaction has been reported by many researchers [18,81,82]. The negative $\mathrm{Zn}-$ phosphorus interaction is one of the most widely studied nutrient interactions $[18,83,84]$. Excess phosphorus in the soil reduces the $\mathrm{Zn}$ availability to a plant. A decrease in uptake of Zn due to a high application dose of phosphorus might be due to reduced Zn concentration in soil solution and reduction in VAM infection resulting decrease in Zn uptake [18]. Zn has also been found to interact negatively with $\mathrm{Fe}, \mathrm{Mn}$, and $\mathrm{Cu}$ [18]. These interactions are to be considered in understanding the availability of $\mathrm{Zn}$ to plant. Soil moisture content has also a significant effect on zin availability. Soil moisture content affects Zn availability by modifying redox potential, $\mathrm{pH}$, and dissolved organic anions [85]. In addition to the chemical characteristics of soil, the biological characters of soil also play a vital role in deciding Zn availability to plants [18,85]. PGPRs refers to a group of bacteria, which have many positive impacts on plant growth [86]. They have the capacity of improving mobility and uptake of nutrients $[18,87,88]$ and have been found to be suitable in improving $\mathrm{Zn}$ availability to plants. The presence of Arbuscular mycorrhiza in soil also plays an important role in mobilizing $\mathrm{Zn}$ to plants [89]. The effectiveness of soil-applied Zn, like any method of $\mathrm{Zn}$ application, also depends on the genetic characters of the plant. The source of zinc and dose of soil zinc application has also been found to affect the outcome in terms of yield and grain quality $[7,18]$. The optimum dose of soil zinc application may vary depending on the crop and soil zinc status. While recommending a zinc dose, care should be taken to avoid zinc toxicity to plants. 


\subsubsection{Foliar Application}

The efficiency of foliar $\mathrm{Zn}$ application greatly depends on the type of fertilizer, crop characteristics, especially, leaf characteristics and genetic potential of the crop [7]. The foliar application gives multiple advantages, such as comparatively low fertilizer requirement, no $\mathrm{Zn}$ fixation, and no influence of antagonist nutrient in the uptake of $\mathrm{Zn}$ [18]. Foliar applied $\mathrm{Zn}$ is phloem mobile [15] and can be transferred to developing grains. In a crop like wheat, foliar application of $\mathrm{Zn}$ has been found to be superior in increasing grain $\mathrm{Zn}$ concentration as compared to soil application $[4,67,68]$. The effectiveness of foliar application on increasing grain $\mathrm{Zn}$ concentration varies significantly with the time of application [11].

A poor correlation between DTPA-Zn concentration of soil and grain Zn concentration has been reported [67]. This lack of correlation may be due to the unfavourable soil conditions that limit their mobilization of nutrients to plant roots and hence their subsequent absorption. As the foliar application does not interact with soil, they are not subjected to any form of fixation. Under unfavourable field conditions, grain $\mathrm{Zn}$ concentration is greatly reliant on the remobilization of this trace element from vegetative tissues (Figure 2) [7,67], hence maintaining a higher concentration of $\mathrm{Zn}$ in the vegetative tissue may improve the grain $\mathrm{Zn}$ concentration [82,90]. Unfavourable field conditions are very normal; therefore, foliar application of $\mathrm{Zn}$ can be a very useful option to increase grain $\mathrm{Zn}$ concentration.

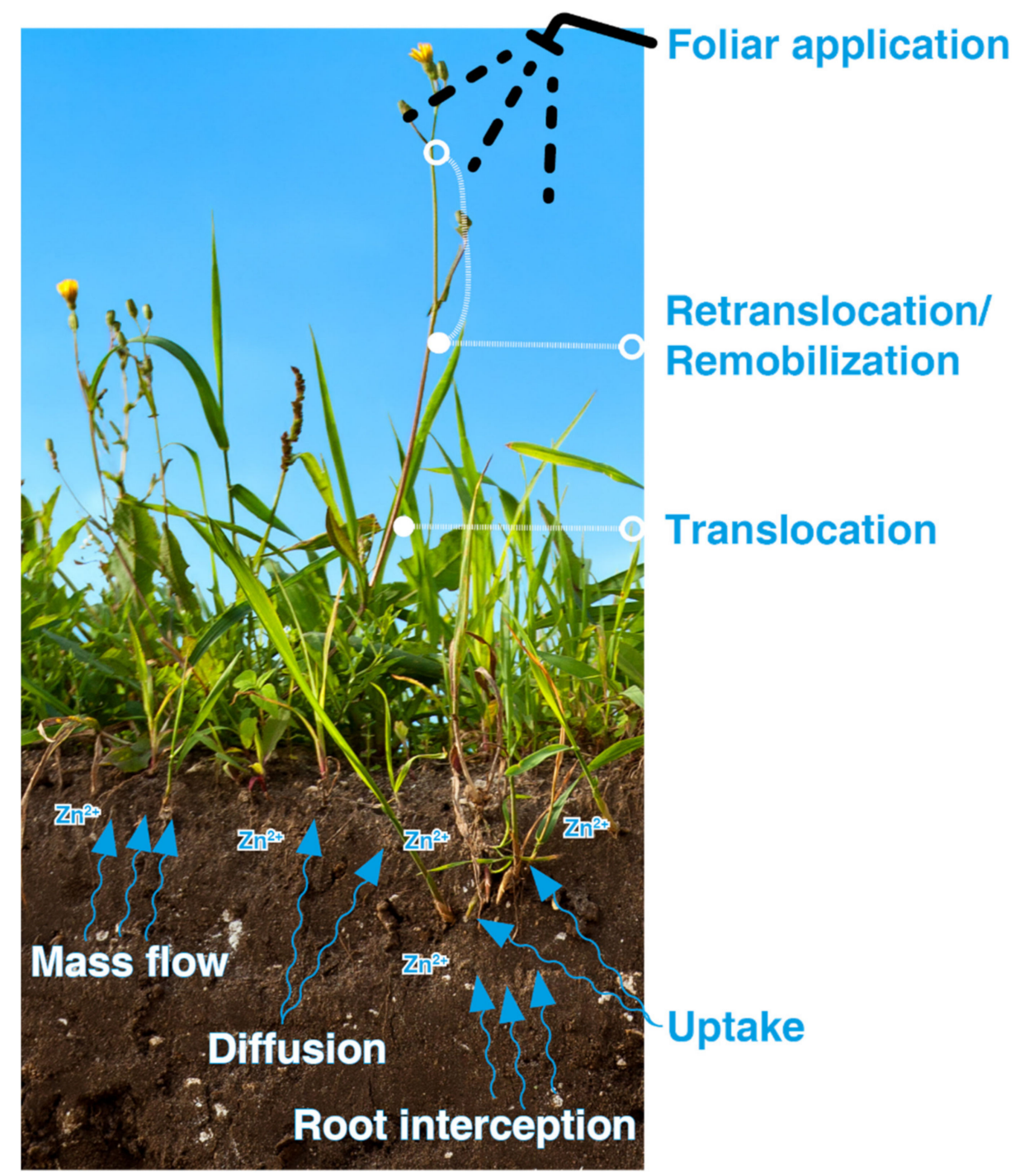

Figure 2. Uptake, translocation, and remobilization of $\mathrm{Zn}$ in plants. 
The time of foliar application is very critical for the effectiveness of foliar-applied $\mathrm{Zn}[91,92]$. Higher grain $\mathrm{Zn}$ enrichment is achieved when $\mathrm{Zn}$ is applied at a later growth stage [91]. Application of $\mathrm{Zn}$ at the heading and early milk stage was found to be more effective than foliar application of $\mathrm{Zn}$ at the booting and stem elongation stage [92]. The higher effectiveness of $\mathrm{Zn}$ applied at the milking stage through the foliar application method might be because of active photo-assimilation allocation to the reproductive sink that caused the mobilization of micronutrients to the sink organs. Stronger phloem mobility of $\mathrm{Zn}$ for foliar application is observed during the reproductive stages [92,93]. Foliar application of $0.5 \%(w / v) \mathrm{ZnSO}_{4} .7 \mathrm{H}_{2} \mathrm{O}$ at the heading and milk stage of wheat resulted in a significant increase in grain $\mathrm{Zn}$ concentration across locations in seven different countries over 2 years of an experiment. The result suggested an average increase in $\mathrm{Zn}$ concentration by $83.5 \%$, while soil $\mathrm{Zn}$ application showed an average increase of $12.3 \%$ over no Zn application [67]. Foliar spray of Zn has also been observed in increasing grain productivity under drought conditions [94] and such improvement in yield under drought condition might be due to improved defence mechanism against stress-induced oxidative cell damage $[67,95]$.

\subsubsection{Seed Application}

High seed $\mathrm{Zn}$ content has been found to improve seedling vigour and crop stand in the field [96]. When plants are grown in a nutrient deficient area then seeds produced will be deficient in nutrients and when such seeds are again resown in a nutrient deficient area then overall seedling vigour, growth, and yield of plants is reduced [96]. As $\mathrm{Zn}$ is transported to plant roots through diffusion, moisture deficiency affects the Zn availability to plant [18]. Thus, soil-applied Zn may not be equally effective in moisture deficient conditions and irrigated conditions. Under the rainfed condition where soil moisture content solely relies on rainfall, the result of $\mathrm{Zn}$ nutrition can be highly inconsistent. Seeds rich in $\mathrm{Zn}$ content could improve plant growth and yield under Zn deficient condition especially under rainfed condition [96].

Seed priming of wheat with Zn significantly increased grain Zn concentration by $12 \%$, while the concentration of chickpea and maize improved by $29 \%$ and $19 \%$, respectively [97]. Seed priming was also found to be cost-effective in all three crops, i.e., wheat, chickpea, and maize [97]. Unlike a foliar application, the effect of seed priming has been noted as less effective in improving grain $\mathrm{Zn}$ concentration [7]; however, they may play an important role especially under resource-poor conditions and stressed environments.

\subsubsection{Combination of Application Methods}

Different combinations of application methods (soil + foliar and seed + foliar) have also been studied to show their effectiveness in improving grain zinc concentration $[68,70,98]$. Combination of soil and foliar application of $\mathrm{Zn}$ has been found to increase the grain $\mathrm{Zn}$ concentration compared to soil or foliar application alone in few experimental locations; while in most of the experimental locations, the combined application showed an at par result with the foliar application alone [67]. Improvement in grain Zn concentration of durum wheat by the combination of soil and foliar application was higher as compared to soil application alone [4].

\subsubsection{Other Agronomic Practices to Improve Zn Uptake}

Nutrient uptake from different application methods may vary due to environmental (soil and atmospheric) and crop characteristics (morphological, physiological, genetic) Agronomic management plays an important role in altering the crop environment, thus agronomic management practices other than $\mathrm{Zn}$ fertilization are also expected to affect Zn uptake.

The moisture status of soil may vary depending on the irrigation practices followed. Moisture deficiency in crop field reduces the diffusion of $\mathrm{Zn}$, limiting their absorption by the plant. Zn deficiency has been observed in rice under contrasting environments, i.e., 
flooded conditions as well as aerobic conditions [18]. In aerobic rice, the soil has more $\mathrm{NO}^{3-}$ ion resulting in more release of $\mathrm{OH}^{-}$from rice roots, which ultimately precipitates Zn thus reducing its' level [99].

In addition to $\mathrm{Zn}$ fertilization, the status of other nutrients in the soil and their application also affects $\mathrm{Zn}$ uptake. Nutrient interaction may alter the availability of nutrients either positively or negatively. A sufficient level of nitrogen supply is very critical for increasing the grain $\mathrm{Zn}$ concentration of wheat. Nitrogen application improves uptake as well as remobilization of $\mathrm{Zn}$ in wheat [100]. The role of nitrogen in improving $\mathrm{Zn}$ biofortification of maize was reported [101]. Unlike nitrogen, phosphorus plays an antagonistic role with $\mathrm{Zn}[83,102]$. Zn has also been found to interact with other micronutrients like iron [103-105], boron [106,107], and copper [108]. The effect of different interactions should be studied to develop a proper $\mathrm{Zn}$ application strategy.

\subsubsection{Additional Benefits of Zn Fertilization}

In addition to enhancing grain $\mathrm{Zn}$ concentration and sometimes yield, agronomic biofortification gives some additional benefits. The soil application of $\mathrm{Zn}$ under a $\mathrm{Zn}$ deficient condition has been found to reduce the uptake and accumulation of phosphorus. This $\mathrm{Zn}$-phosphorus antagonism is one of the most discussed nutrient antagonisms. The reduced phosphorus uptake and accumulation may reduce the phytate content in grains [11] Under Zn deficiency, the uptake and shoot accumulation of phosphorus increases, which results in a corresponding increase of phosphorus in grain due to high phloem mobility of phosphorus [11,109]. Most of the inorganic phosphorus in grains is transformed into phytic acid. As phytate is considered as an antinutritional factor and reduces the bioavailability of $\mathrm{Zn}[110,111]$, low phytic acid in grains will improve Zn bioavailability. The phytate-Zn molar ratio is used as an indicator for estimating Zn bioavailability [112].

In addition to human health benefits, grains enriched with $\mathrm{Zn}$ can give additional agronomic benefits. Seeds with low $\mathrm{Zn}$ concentration show poor tolerance to environmental stresses [113]. When seeds with low Zn concentration are grown on Zn deficient soil, it results in poor crop establishment and seedling vigour [96]. Maintaining a sufficient level of seed $\mathrm{Zn}$ also provides defence against soil-borne pathogens [11]. As Zn rich seeds improve seedling vigour and crop establishment the seeding rate may be decreased [11,114].

\subsection{Genetic Biofortification}

The second approach for enhancing grain Zn concentration in crops is genetic biofortification. Genetic biofortification follows the breeding approach to increase the concentration and bioavailability of grain $\mathrm{Zn}$. Genetic biofortification can serve as a cost-effective strategy to alleviate Zn deficiency. A superior genotype, once developed, can be used for many years without any additional recurring cost.

\subsubsection{Strategies for Genetic Biofortification}

Plant breeding and/or transgenic approaches provide a hopeful and long-term strategy to overcome micronutrient malnutrition by developing genotypes with a high level of $\mathrm{Zn}$ in the edible plant parts $[16,34,67]$. Though the cost of developing a genotype is costly and time-consuming, it gives a long term benefit as it does not involve any recurring cost. Breeding for high grain $\mathrm{Zn}$ concentration is possible as sufficient genetic variation is found in the germplasms of major cereal crops [115].

The overall steps involved in breeding include the following minimum steps: finding suitable genetic variation and selection of parents, long term crossing and backcrossing, stabilization of target traits across multiple environments/climatic conditions, and adaptation of the biofortified genotypes to the regional agronomic management practices [11]. The breeding criteria for micronutrient enriched food crops as outlined by Welch and Graham [16] are: crop productivity must be maintained or increased, achieve a micronutrient level that can have a significant impact on human health, stability of micronutrient enrichment traits across the various edaphic environment and climatic zones, the bioavailability 
of micronutrients in humans should be sufficient to improve micronutrient levels of people "preparing and eating them in traditional ways within normal household environments", and consumer acceptance must be tested. In the past century, a significant increase in grain yield was observed owing to a breeding strategy especially attempting to increase crop productivity and improved agronomic practices. Such an increase in yield was very marked during the green revolution period. With the rise in grain yield, a considerable decrease in the grain Zn was observed due to the "dilution effect" [15,116,117].

A superior genotype for $\mathrm{Zn}$ biofortification needs to have the following characteristics: high $\mathrm{Zn}$ acquisition efficiency, readily translocate $\mathrm{Zn}$ to grain/edible part of plant, efficient remobilization of $\mathrm{Zn}$ from vegetative tissues to grain or edible part of the plant, and availability of $\mathrm{Zn}$ in the plant in a bioavailable form that can be utilized by the person consuming it $[14,118]$. Several genes are involved in controlling those characteristics. As the performance of any type is affected by the environment the performance stability of the genotypes must be evaluated at multiple locations over a reasonable period to confirm their efficiency. While breeding biofortified varieties, care must be taken not to compromise the end-use characteristics so that it can be quickly adopted by consumers as well as producers [4]. As consumer preference varies over locations care must be taken to develop a variety that appeals to consumer taste or sensory preferences.

Existing genetic variability, trait heritability, gene action, the association among traits, available screening techniques, and diagnostic tools are commonly used criteria to estimate the potential genetic gains [4]. A large genetic variation for grain $\mathrm{Zn}$ concentration exists among modern wheat genotypes and their wild relatives [11,67]. This genetic variation can be beneficially exploited under different breeding programs. Combining high grain Zn concentrations with a high yield under different environmental conditions is very important for a successful genetic biofortification strategy.

In addition to grain $\mathrm{Zn}$ concentration, the bioavailability of the $\mathrm{Zn}$ should be given importance in the breeding programs. Only $25 \%$ of the $\mathrm{Zn}$ in the staple food grains are thought to be bioavailable [14]. The bioavailability of micronutrients is often limited by antinutrient factors like phytic acid. Though genotypes can be bred for low antinutritional factor, care should be taken as many antinutritional factors play role in plant metabolism and provide resistance against biotic and abiotic stress [14,119]. Moreover, antinutrients like polyphenols and phytate in human diets provide multiple health benefits by acting as an anti-carcinogen and antidiabetic [120-122]. Phytic acid in seeds also plays an important role in seed germination and good seed vigour $[11,123,124]$. Hence, a proper balance should be found to get the benefits of antinutritional factors while maintaining sufficient bioavailable $\mathrm{Zn}$ level in the grain. The $\mathrm{Zn}$ that will actually be bioavailable after harvesting, processing, and cooking needs to be evaluated to get a clearer picture of the actual benefit that can be harnessed through biofortification.

A transgenic approach can be followed to develop crop varieties with a high $\mathrm{Zn}$ content. Evidence of ZIP family iron and Zn transporter proteins in improving grain micronutrient concentration is available $[11,125,126]$. These transporter proteins are involved in the uptake and transport of cationic micronutrients. The expression of a $\mathrm{Zn}$ transporter gene from Arabidopsis thaliana in barley roots increased the $\mathrm{Zn}$ concentration in grain [127].

\subsubsection{Limitations and Constraints of Genetic Biofortification}

In the agronomic biofortification section, we have briefly discussed how various soil characteristics affect a plant's availability of $\mathrm{Zn}$. Under such a condition, the varieties developed to accumulate more $\mathrm{Zn}$ in the edible parts may not be able to show its full potential. To achieve a grain $\mathrm{Zn}$ concentration in the edible portions of the plant that can bring a measurable biological impact, the plant must be grown in a soil environment with sufficient plant-available Zn [11]. As the majority of the world soils under cereal cultivation have adverse chemical properties $\mathrm{Zn}$ nutrition to crops grown under such condition is impaired [11,80,128,129]. 
Moreover, crop improvement to develop $\mathrm{Zn}$ rich variety is a fairly lengthy process and requires a lot of effort in germplasm selection/screening, crossing, and performance assessment in the multilocation trial. However, as $\mathrm{Zn}$ concentration is not subjected to genetic erosion, little maintenance breeding is needed after the incorporation of the desired gene into the gene pool [4].

\section{Combining Agronomic and Genetic Biofortification}

The success of genetic biofortification may be jeopardized if sufficient $\mathrm{Zn}$ is not available in soil [11]. The capacity of plants to absorb sufficient $\mathrm{Zn}$ from the soil will not be enough unless there is sufficient $\mathrm{Zn}$ in the soil available to be absorbed. Hence, a suitable genotype capable of absorption and translocation of $\mathrm{Zn}$ towards the grain efficiently when supplied with sufficient plant-available $\mathrm{Zn}$ is expected to give the best possible result (Figure 3). As genetic biofortification takes a comparatively longer time, agronomic biofortification may serve as a complementary approach to achieve high grain $\mathrm{Zn}$ to some extent. Selection of suitable variety when combined with the right application method and right fertilizer application method could improve micronutrient concentration in different crops [92].

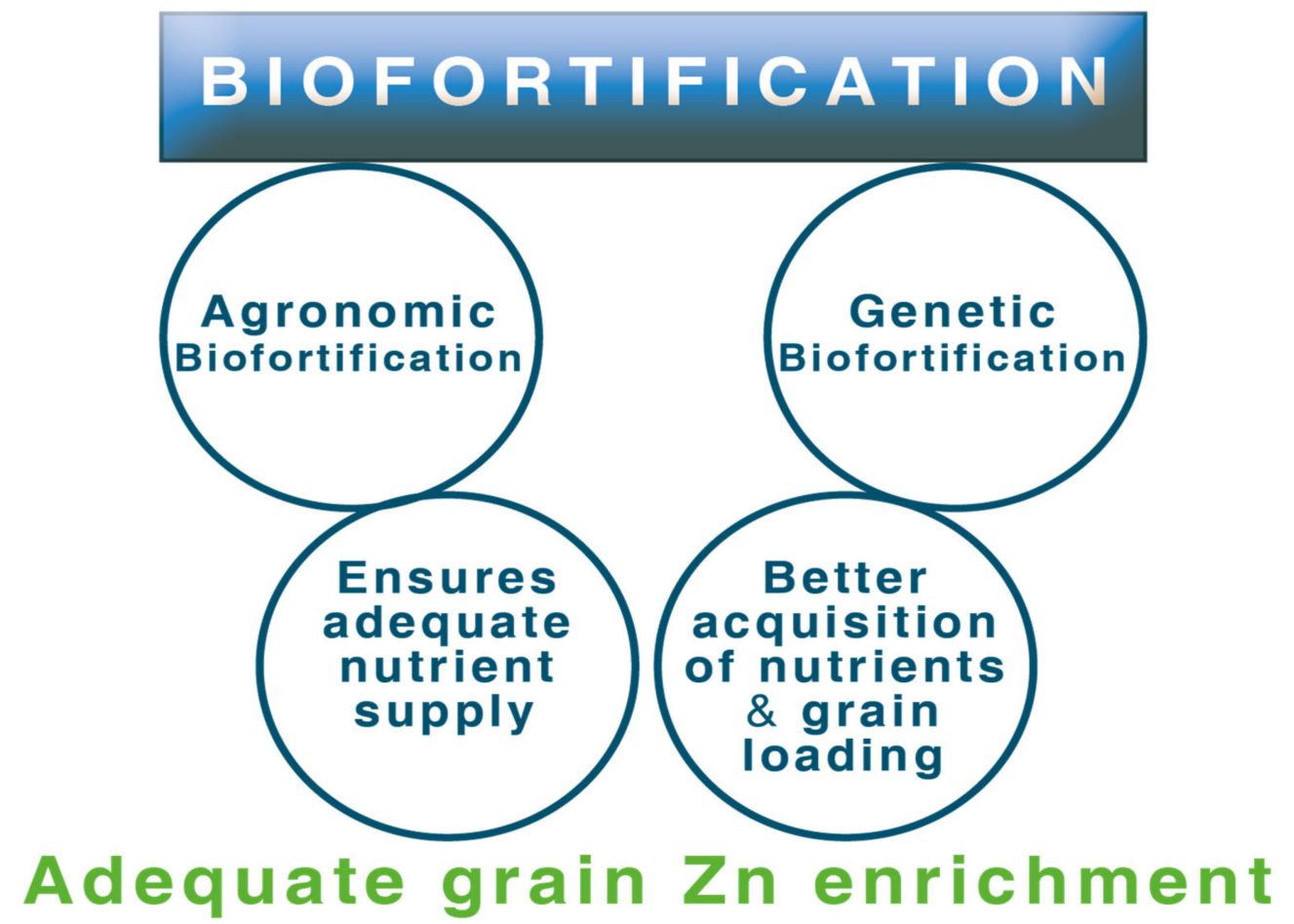

Figure 3. Complimentary effect of agronomic and genetic biofortification.

\section{Economic Points of View for Zn Biofortification}

The unavailability and unaffordability of a healthy diet are largely responsible for the prevalence of malnutrition across the globe. As per an estimate, over 3 billion people worldwide are far from easy access to a healthy diet. Thus, both accessibility and affordability of a healthy diet must be ensured. By 2030, diet-related health cost linked to death and non-communicable diseases are expected to exceed USD 1.3 trillion while, the diet-related social cost of GHG (greenhouse gas) emission is projected to be greater than USD 1.7 trillion. Though these costs are often ignored, a dietary shift to a healthy diet can reduce the cost related to health and climate change. In fact, adoption of a healthy diet can reduce the direct and indirect health costs up to $97 \%$ and a $41-74 \%$ reduction in social cost in GHG emission by 2030 [3].

As the application of Zn may not necessarily increase the yield, farmers may be sceptical to apply $\mathrm{Zn}$ as it incurs an additional cost. However, the health benefits obtained from 
Zn application are usually overlooked in such conditions. Zn and other micronutrient deficiency cause huge economic losses in developing countries and have a huge impact on gross domestic product (GDP) and costs related to health care $[15,130]$. Micronutrient deficiency is responsible for economic cost at the individual, community, and national levels [130]. Hence, an appropriate policy to encourage and incentivize farmers for producing $\mathrm{Zn}$ enriched grains is required.

Wang et al. [131] calculated the cost-effectiveness of agronomic biofortification by using the "disability-adjusted life year" to calculate the health issues. They found that agronomic biofortification of wheat with $\mathrm{Zn}$ could improve the dietary intake of $\mathrm{Zn}$ among infants and children below five-years of age, consequently reducing $\mathrm{Zn}$ deficiency-related health burdens by up to $56.6 \%$ in the study region. They also showed that US $\$ 226$ to US \$594 is required to save one "disability-adjusted life year" when the foliar spray of Zn is done alone, while, with foliar application of $\mathrm{Zn}$ fertilizer is combined with pesticide spray, the labour cost drops, and only US $\$ 41$ to US $\$ 108$ is required to save one "disabilityadjusted life year".

The suboptimal utilization of the human resource potential is expected to reduce the work productivity and thus will have an undesirable impact on economic output at all levels, starting from the individual to the national level. Intervention is required to reduce micronutrient malnutrition so that human resource potential can be fully utilized to their potential and cost of health can be reduced. Biofortification may be seen as an investment in human health, which will also reduce the cost of health. Unless we evaluate this health benefit of biofortified grains and see grain yield as the only criteria for evaluating the economic output of crop production; then the benefits of biofortification can be hardly realized. Social awareness on the importance of micronutrient nutrition, policies to promote micronutrient application in crops to realize the benefits of agronomic and/or genetic biofortification, and investment in the research and development on biofortification can help in sustainably alleviating micronutrient malnutrition.

\section{Future Scopes}

Though research has advanced in biofortification, some key areas need to be addressed or improved further. Some have been highlighted below:

- A comprehensive 4R (right place, right time, right source, and right dose) approach of $\mathrm{Zn}$ application can be developed for different crops at the regional level and the best combination can be found for achieving high grain Zn concentration.

- Physiological constraints of grain $\mathrm{Zn}$ accumulation must be identified for different crops under different conditions and agronomic and genetic approaches for ameliorating these constraints may be found to further improve the grain Zn density.

- Biofortification options must be studied under stressed environments and their effects must be evaluated under such conditions. As climate change is expected to bring more weather anomalies, a stress-proof biofortification approach must be developed.

- The bioavailability of $\mathrm{Zn}$ obtained through foliar application can be compared with other application methods. Agronomic management that improves grain $\mathrm{Zn}$ bioavailability should be studied.

- The environmental implications of continuous $\mathrm{Zn}$ application should be studied. Continuous application of $\mathrm{Zn}$ over a long period may cause $\mathrm{Zn}$ toxicity and therefore should be regularly monitored.

- The performance of $\mathrm{Zn}$-efficient genotypes under different soil $\mathrm{Zn}$ availability should be evaluated. The beneficial effects of combining the agronomic and genetic biofortification approach should be explored.

\section{Conclusions}

From this comprehensive review, it can be concluded that the biofortification approach has outstanding potential for ameliorating the problem of micronutrient malnutrition. The cost-effectiveness of this approach makes it a suitable option for low-income countries. As 
biofortification improves the micronutrient concentration of the staple food grains that is predominantly consumed by people it does not involve any dietary change and can be adapted by people quickly. Agronomic biofortification not only improves the grain $\mathrm{Zn}$ concentration providing health benefits, but it can also help in reducing the extent of $\mathrm{Zn}$ deficiency especially in regions where intensive cropping is practiced and micronutrient application is overlooked. With the advent of genetic engineering and molecular tools, the breeding approach of biofortification can also be fastened and developing a superior $\mathrm{Zn}$-efficient and $\mathrm{Zn}$-rich varieties will be comparatively easier to find. Policy initiative and government support will also help in further research and dissemination of biofortification technologies and practices.

Author Contributions: Conceptualization, S.P., A.H., M.S., S.M., T.S., and P.B.; writing-original draft preparation, S.P., A.H., M.S., S.M., T.S., and P.B.; writing-review and editing, V.H., P.V., and M.B.; funding acquisition, M.S., V.H., P.V., and M.B. All authors have read and agreed to the published version of the manuscript.

Funding: This study was supported by an S-grant from the Ministry of Education, Youth and Sports of the Czech Republic.

Institutional Review Board Statement: Not applicable.

Informed Consent Statement: Not applicable.

Data Availability Statement: Most of the recorded data are available in the Tables and Figures of the manuscript.

Acknowledgments: Authors extend their appreciation to the editor and anonymous reviewers for their valuable comments, which have allowed for considerable improvement of the review.

Conflicts of Interest: The authors declare no conflict of interest.

\section{References}

1. Gundersen, C.; Ziliak, J.P. Food Insecurity and Health Outcomes. Health Aff. 2015, 34, 1830-1839. [CrossRef]

2. Onyango, A.W. Dietary diversity, child nutrition and health in contemporary African communities. Comp. Biochem. Physiol. Part A Mol. Integr. Physiol. 2003, 136, 61-69. [CrossRef]

3. FAO; IFAD; UNICEF; WFP; WHO. The State of Food Security and Nutrition in the World 2020: Transforming Food Systems for Affordable Healthy Diets; FAO: Rome, Italy, 2020.

4. Cakmak, I.; Pfeiffer, W.H.; McClafferty, B. REVIEW: Biofortification of Durum Wheat with Zinc and Iron. Cereal Chem. J. 2010, 87, 10-20. [CrossRef]

5. Cakmak, I.; Graham, R.; Welch, R.M. Agricultural and molecular genetic approaches to improving nutrition and preventing micronutrient malnutrition globally. Encycl. Life Support Syst. 2002, 1, 1075-1099.

6. Velu, G.; Ortiz-Monasterio, I.; Cakmak, I.; Hao, Y.; Singh, R. Biofortification strategies to increase grain zinc and iron concentrations in wheat. J. Cereal Sci. 2014, 59, 365-372. [CrossRef]

7. Zaman, Q.U.; Aslam, Z.; Yaseen, M.; Ihsan, M.Z.; Khaliq, A.; Fahad, S.; Bashir, S.; Ramzani, P.M.A.; Naeem, M. Zinc biofortification in rice: Leveraging agriculture to moderate hidden hunger in developing countries. Arch. Agron. Soil Sci. 2018, 64, 147-161. [CrossRef]

8. Ruel, M.T.; Alderman, H.; Maternal and Child Nutrition Study Group. Nutrition-sensitive interventions and programmes: How can they help to accelerate progress in improving maternal and child nutrition? Lancet 2013, 382, 536-551. [CrossRef]

9. De Valença, A.; Bake, A.; Brouwer, I.; Giller, K. Agronomic biofortification of crops to fight hidden hunger in sub-Saharan Africa. Glob. Food Secur. 2017, 12, 8-14. [CrossRef]

10. Aciksoz, S.B.; Yazici, A.; Ozturk, L.; Cakmak, I. Biofortification of wheat with iron through soil and foliar application of nitrogen and iron fertilizers. Plant Soil 2011, 349, 215-225. [CrossRef]

11. Cakmak, I. Enrichment of cereal grains with zinc: Agronomic or genetic biofortification? Plant Soil 2008, 302, 1-17. [CrossRef]

12. Das, S.; Chaki, A.K.; Hossain, A. Breeding and agronomic approaches for the biofortification of zinc in wheat (Triticum aestivum L.) to combat zinc deficiency in millions of a population: A Bangladesh perspective. Acta Agrobot. 2019, 72. [CrossRef]

13. Maqbool, M.A.; Beshir, A. Zinc biofortification of maize (Zea mays L.): Status and challenges. Plant Breed. 2019, 138, 1-28. [CrossRef]

14. Bouis, H.E.; Welch, R.M. Biofortification-A Sustainable Agricultural Strategy for Reducing Micronutrient Malnutrition in the Global South. Crop Sci. 2010, 50, S-20-S-32. [CrossRef]

15. Cakmak, I.; Kutman, U.B. Agronomic biofortification of cereals with zinc: A review. Eur. J. Soil Sci. 2018, 69, 172-180. [CrossRef] 
16. Welch, R.M.; Graham, R.D. Breeding for micronutrients in staple food crops from a human nutrition perspective. J. Exp. Bot. 2004, 55, 353-364. [CrossRef] [PubMed]

17. Yaseen, M.K.; Hussain, S. Zinc-biofortified wheat required only a medium rate of soil zinc application to attain the targets of zinc biofortification. Arch. Agron. Soil Sci. 2021, 67, 551-562. [CrossRef]

18. Prasad, R.; Shivay, Y.S.; Kumar, D. Agronomic Biofortification of Cereal Grains with Iron and Zinc. Adv. Agron. 2014, 125, 55-91. [CrossRef]

19. Wessells, K.R.; Brown, K.H. Estimating the global prevalence of zinc deficiency: Results based on zinc availability in national food supplies and the prevalence of stunting. PLoS ONE 2012, 7, e50568. [CrossRef]

20. Gibson, R.S. Zinc deficiency and human health: Etiology, health consequences, and future solutions. Plant Soil 2012, 361, 291-299. [CrossRef]

21. Hotz, C.; Brown, K.H. Assessment of the risk of zinc deficiency in populations and options for its control. Food Nutr. Bull. 2004, 25, S91-S204.

22. Prasad, R. Crop Nutrition-Principles and Practices; New Vishal Publications: Delhi, India, 2007; p. 272.

23. Roohani, N.; Hurrell, R.; Kelishadi, R.; Schulin, R. Zinc and its importance for human health: An integrative review. J. Res. Med. Sci. 2013, 18, 144-157. [PubMed]

24. Tapiero, H.; Tew, K.D. Trace elements in human physiology and pathology: Zinc and metallothioneins. Biomed. Pharmacother. 2003, 57, 399-411. [CrossRef]

25. Zastrow, M.L.; Pecoraro, V.L. Designing Hydrolytic Zinc Metalloenzymes. Biochemistry 2014, 53, 957-978. [CrossRef] [PubMed]

26. Maret, W. Zinc Biochemistry: From a Single Zinc Enzyme to a Key Element of Life. Adv. Nutr. 2013, 4, 82-91. [CrossRef]

27. Hambidge, K.M. Zinc deficiency in young children. Am. J. Clin. Nutr. 1997, 65, 160-161. [CrossRef]

28. Veenemans, J.; Milligan, P.; Prentice, A.M.; Schouten, L.R.; Inja, N.; Van Der Heijden, A.C.; De Boer, L.C.; Jansen, E.J.; Koopmans, A.E.; Enthoven, W.T.; et al. Effect of supplementation with zinc and other micronutrients on malaria in Tanzanian children: A randomised trial. PLoS Med. 2011, 8, e1001125. [CrossRef]

29. Bhutta, Z.; Black, R.; Brown, K.; Gardner, J.; Gore, S.; Hidayat, A.; Khatun, F.; Martorell, R.; Ninh, N.; Penny, M.; et al. Prevention of diarrhea and pneumonia by zinc supplementation in children in developing countries: Pooled analysis of randomized controlled trials. J. Pediatr. 1999, 135, 689-697. [CrossRef]

30. Moretti, D.; Biebinger, R.; Bruins, M.J.; Hoeft, B.; Kraemer, K. Bioavailability of iron, zinc, folic acid, and vitamin A from fortified maize. Ann. N. Y. Acad. Sci. 2013, 1312, 54-65. [CrossRef]

31. Udechukwu, M.C.; Collins, S.A.; Udenigwe, C.C. Prospects of enhancing dietary zinc bioavailability with food-derived zincchelating peptides. Food Funct. 2016, 7, 4137-4144. [CrossRef]

32. Saha, S.; Chakraborty, M.; Padhan, D.; Saha, B.; Murmu, S.; Batabyal, K.; Seth, A.; Hazra, G.C.; Mandal, B.; Bell, R.W. Agro-nomic biofortification of zinc in rice: Influence of cultivars and zinc application methods on grain yield and zinc bioavailability. Field Crops Res. 2017, 210, 52-60. [CrossRef]

33. Sharma, A.; Patni, B.; Shankhdhar, D.; Shankhdhar, S.C. Zinc-An indispensable micronutrient. Physiol. Mol. Biol. Plants 2013, 19, 11-20. [CrossRef] [PubMed]

34. White, P.J.; Broadley, M. Biofortifying crops with essential mineral elements. Trends Plant Sci. 2005, 10, 586-593. [CrossRef]

35. Chasapis, C.; Loutsidou, A.C.; Spiliopoulou, C.A.; Stefanidou, M.E. Zinc and human health: An update. Arch. Toxicol. 2012, 86, 521-534. [CrossRef] [PubMed]

36. Shokrzadeh, M.; Ghaemian, A.; Salehifar, E.; Aliakbari, S.; Saravi, S.S.S.; Ebrahimi, P. Serum Zinc and Copper Levels in Ischemic Cardiomyopathy. Biol. Trace Elem. Res. 2008, 127, 116-123. [CrossRef]

37. Ogawa, Y.; Kinoshita, M.; Shimada, S.; Kawamura, T. Zinc and Skin Disorders. Nutrients 2018, 10, 199. [CrossRef]

38. Lansdown, A.B.G.; Mirastschijski, U.; Stubbs, N.; Scanlon, E.; Ågren, M.S. Zinc in wound healing: Theoretical, experimental, and clinical aspects. Wound Repair Regen. 2007, 15, 2-16. [CrossRef] [PubMed]

39. Schwartz, J.R.; Marsh, R.G.; Draelos, Z.D. Zinc and Skin Health: Overview of Physiology and Pharmacology. Dermatol. Surg. 2006, 31, 837-847. [CrossRef] [PubMed]

40. Rostan, E.F.; DeBuys, H.V.; Madey, D.L.; Pinnell, S.R. Evidence supporting zinc as an important antioxidant for skin. Int. J. Dermatol. 2002, 41, 606-611. [CrossRef]

41. Favier, A.E. The role of zinc in reproduction. Hormonal mechanism. Biol. Trace Elem. Res. 1992, 32, 363-382. [CrossRef] [PubMed]

42. Kumar, N.; Singh, A.K. Role of Zinc in Male Infertility: Review of Literature. Indian J. Obstet. Gynecol. Res. 2016, 3, 167. [CrossRef]

43. Baltaci, A.K.; Mogulkoc, R.; Baltaci, S.B. Review: The role of zinc in the endocrine system. Pak. J. Pharm. Sci. 2019, 32, 231-239.

44. Frederickson, C.J.; Suh, S.W.; Silva, D.; Frederickson, C.J.; Thompson, R.B. Importance of zinc in the central nervous system: The zinc-containing neuron. J. Nutr. 2000, 130, 1471S-1483S. [CrossRef]

45. Gower-Winter, S.D.; Levenson, C.W. Zinc in the central nervous system: From molecules to behavior. BioFactors 2012, 38, 186-193. [CrossRef]

46. Brown, K.H.; Rivera, J.A.; Bhutta, Z.; Gibson, R.S.; King, J.C.; Lönnerdal, B.; Ruel, M.T.; Sandtröm, B.; Wasantwisut, E.; Hotz, C. International Zinc Nutrition Consultative Group (IZiNCG) technical document \#1. Assessment of the risk of zinc deficiency in populations and options for its control. Food Nutr. Bull. 2004, 25 (Suppl. 2), S99-S203. [PubMed]

47. Barnett, J.B.; Hamer, D.H.; Meydani, S.N. Low zinc status: A new risk factor for pneumonia in the elderly? Nutr. Rev. 2010, 68, 30-37. [CrossRef] [PubMed] 
48. Brown, P.H.; Cakmak, I.; Zhang, Q. Form and Function of Zinc Plants. In Zinc in Soils and Plants; Springer: Dordrecht, The Netherlands, 1993; pp. 93-106.

49. Tobin, A.J. Carbonic Anhydrase from Parsley Leaves. J. Biol. Chem. 1970, 245, 2656-2666. [CrossRef]

50. Du, H.Y.; Liu, D.X.; Liu, G.T.; Liu, H.P.; Kurtenbach, R. Relationship between Polyamines and Anaerobic Respiration of Wheat Seedling Root under Water-Logging Stress. Russ. J. Plant Physiol. 2018, 65, 874-881. [CrossRef]

51. Miro, B.; Ismail, A.M. Tolerance of anaerobic conditions caused by flooding during germination and early growth in rice (Oryza sativa L.). Front. Plant Sci. 2013, 4, 269. [CrossRef]

52. Alscher, R.G.; Erturk, N.; Heath, L.S. Role of superoxide dismutases (SODs) in controlling oxidative stress in plants. J. Exp. Bot. 2002, 53, 1331-1341. [CrossRef]

53. Wang, Y.; Branicky, R.; Noë, A.; Hekimi, S. Superoxide dismutases: Dual roles in controlling ROS damage and regulating ROS signaling. J. Cell Biol. 2018, 217, 1915-1928. [CrossRef]

54. Lu, Y.; Hall, D.A.; Last, R.L. A small zinc finger thylakoid protein plays a role in maintenance of photosystem II in Arabidopsis thaliana. Plant Cell 2011, 23, 1861-1875. [CrossRef] [PubMed]

55. Disante, K.B.; Fuentes, D.; Cortina, J. Response to drought of Zn-stressed Quercus suber L. seedlings. Environ. Exp. Bot. 2011, 70, 96-103. [CrossRef]

56. Hafeez, B.; Khanif, Y.M.; Saleem, M. Role of Zinc in Plant Nutrition-A Review. Am. J. Exp. Agric. 2013, 3, 374-391. [CrossRef]

57. Kasim, W.A. Physiological consequences of structural and ultra-structural changes induced by Zn stress in Phaseolus vulgaris. I. Growth and Photosynthetic apparatus. Int. J. Bot. 2007, 3, 15-22. [CrossRef]

58. Peck, A.W.; McDonald, G.K. Adequate zinc nutrition alleviates the adverse effects of heat stress in bread wheat. Plant Soil 2010, 337, 355-374. [CrossRef]

59. Tavallali, V.; Rahemi, M.; Eshghi, S.; Kholdebarin, B.; Ramezanian, A. Zinc alleviates salt stress and increases antioxidant enzyme activity in the leaves of pistachio (Pistacia vera L. 'Badami') seedlings. Turk. J. Agric. Forest. 2010, 34, 349-359.

60. Jan, A.; Maruyama, K.; Todaka, D.; Kidokoro, S.; Abo, M.; Yoshimura, E.; Shinozaki, K.; Nakashima, K.; Yamaguchi-Shinozaki, K. OsTZF1, a CCCH-Tandem Zinc Finger Protein, Confers Delayed Senescence and Stress Tolerance in Rice by Regulating Stress-Related Genes. Plant Physiol. 2013, 161, 1202-1216. [CrossRef]

61. Zhang, H.; Liu, Y.; Wen, F.; Yao, D.; Wang, L.; Guo, J.; Ni, L.; Zhang, A.; Tan, M.; Jiang, M. A novel rice C2H2-type zinc finger protein, ZFP36, is a key player involved in abscisic acid-induced antioxidant defence and oxidative stress tolerance in rice. J. Exp. Bot. 2014, 65, 5795-5809. [CrossRef] [PubMed]

62. Guo, Y.; Yu, Y.; Wang, D.; Wu, C.; Yang, G.; Huang, J.; Zheng, C. GhZFP1, a novel CCCH-type zinc finger protein from cotton, enhances salt stress tolerance and fungal disease resistance in transgenic tobacco by interacting with GZIRD21A and GZIPR5. New Phytol. 2009, 183, 62-75. [CrossRef]

63. Li, C.; Lv, J.; Zhao, X.; Ai, X.; Zhu, X.; Wang, M.; Zhao, S.; Xia, G. TaCHP: A Wheat Zinc Finger Protein Gene Down-Regulated by Abscisic Acid and Salinity Stress Plays a Positive Role in Stress Tolerance. Plant Physiol. 2010, 154, 211-221. [CrossRef]

64. Cabot, C.; Martos, S.; Llugany, M.; Gallego, B.; Tolrà, R.; Poschenrieder, C. A Role for Zinc in Plant Defense against Pathogens and Herbivores. Front. Plant Sci. 2019, 10, 1171. [CrossRef]

65. Khoshgoftarmanesh, A.H.; Schulin, R.; Chaney, R.L.; Daneshbakhsh, B.; Afyuni, M. Micronutrient-efficient genotypes for crop yield and nutritional quality in sustainable agriculture-A review. Agron. Sustain. Dev. 2010, 30, 83-107. [CrossRef]

66. McDonald, G.K.; Genc, Y.; Graham, R.D. A simple method to evaluate genetic variation in grain zinc concentration by correcting for differences in grain yield. Plant Soil 2008, 306, 49-55. [CrossRef]

67. Zou, C.Q.; Zhang, Y.Q.; Rashid, A.; Ram, H.; Savasli, E.; Arisoy, R.Z.; Ortiz-Monasterio, I.; Simunji, S.; Wang, Z.H.; Sohu, V.S.; et al. Biofortification of wheat with zinc through zinc fertilization in seven countries. Plant Soil 2012, 361, 119-130. [CrossRef]

68. Yilmaz, A.; Ekiz, H.; Torun, B.; Gultekin, I.; Karanlik, S.; Bagci, S.A.; Cakmak, I. Effect of different zinc application methods on grain yield and zinc concentration in wheat cultivars grown on zinc-deficient calcareous soils. J. Plant Nutr. 1997, 20, 461-471. [CrossRef]

69. Khan, M.U.; Qasim, M.; Subhan, M.; Jamil, M.; Ahmad, R.D. Response of rice to different methods of zinc application in calcareous soil. Pak. J. Appl. Sci. 2003, 3, 524-529. [CrossRef]

70. Mathpal, B.; Srivastava, P.C.; Shankhdhar, D.; Shankhdhar, S.C. Zinc enrichment in wheat genotypes under various methods of zinc application. Plant Soil Environ. 2015, 61, 171-175. [CrossRef]

71. Hussain, S.; Maqsood, M.A.; Rengel, Z.; Aziz, T. Biofortification and estimated human bioavailability of zinc in wheat grains as influenced by methods of zinc application. Plant Soil 2012, 361, 279-290. [CrossRef]

72. Rehman, A.; Farooq, M.; Ahmad, R.; Basra, S. Seed priming with zinc improves the germination and early seedling growth of wheat. Seed Sci. Technol. 2015, 43, 262-268. [CrossRef]

73. Lindsay, W.L.; Mortvedt, J.J. Inorganic Equilibria Affecting Micronutrients in Soils. Micronutr. Agric. 2018, 4, 89-112. [CrossRef]

74. Alloway, B.J. Soil factors associated with zinc deficiency in crops and humans. Environ. Geochem. Health 2009, 31, 537-548. [CrossRef]

75. Sparks, D.L. Kinetics of Soil Chemical Phenomena: Future Directions. Future Prospect. Soil Chem. 2015, 55, 81-101. [CrossRef]

76. Tye, A.; Young, S.; Crout, N.; Zhang, H.; Preston, S.; Barbosa-Jefferson, V.; Davison, W.; McGrath, S.; Paton, G.; Kilham, K.; et al. Predicting the activity of $\mathrm{Cd}^{2+}$ and $\mathrm{Zn}^{2+}$ in soil pore water from the radio-labile metal fraction. Geochim. Cosmochim. Acta 2003, 67, 375-385. [CrossRef] 
77. Wilkinson, H.F.; Loneragan, J.F.; Quirk, J.P. The Movement of Zinc to Plant Roots1. Soil Sci. Soc. Am. J. 1968, $32,831-833$. [CrossRef]

78. Rengel, Z. Availability of Mn, Zn and Fe in the rhizosphere. J. Soil Sci. Plant Nutr. 2015, 15, 397-409. [CrossRef]

79. Cakmak, I.; Yilmaz, A.; Ekiz, H.; Torun, B.; Erenoglu, B.; Braun, H.J. Zinc deficiency as a critical nutritional problem in wheat production in Central Anatolia. Plant Soil 1996, 180, 165-172. [CrossRef]

80. Graham, R.D.; Ascher, J.S.; Hynes, S.C. Selecting zinc-efficient cereal genotypes for soils of low zinc status. Plant Soil 1992, 146, 241-250. [CrossRef]

81. Erenoglu, E.B.; Kutman, U.B.; Ceylan, Y.; Yildiz, B.; Cakmak, I. Improved nitrogen nutrition enhances root uptake, root-to-shoot translocation and remobilization of zinc ( $65 \mathrm{Zn}$ ) in wheat. New Phytol. 2011, 189, 438-448. [CrossRef]

82. Kutman, U.B.; Yildiz, B.; Ozturk, L.; Cakmak, I. Biofortification of durum wheat with zinc through soil and foliar applications of nitrogen. Cereal Chem. 2010, 87, 1-9. [CrossRef]

83. Mousavi, S.R. Zinc in crop production and interaction with phosphorus. Aust. J. Basic Appl. Sci. 2011, 5, 1503-1509.

84. Prasad, R.; Shivay, Y.S.; Kumar, D. Interactions of zinc with other nutrients in soils and plants-A Review. Indian J. Fertil. 2016, 12, 16-26.

85. Gao, X.; Hoffland, E.; Stomph, T.; Grant, C.A.; Zou, C.; Zhang, F. Improving zinc bioavailability in transition from flooded to aerobic rice. A review. Agron. Sustain. Dev. 2012, 32, 465-478. [CrossRef]

86. Aeron, A.; Kumar, S.; Pandey, P.; Maheshwari, D.K. Emerging role of plant growth promoting rhizobacteria in agrobiology. In Bacteria in Agrobiology: Crop Ecosystems; Springer: Berlin/Heidelberg, Germany, 2011; pp. 1-36.

87. Cakmakçi, R.; Dönmez, F.; Aydın, A.; Şahin, F. Growth promotion of plants by plant growth-promoting rhizobacteria under greenhouse and two different field soil conditions. Soil Biol. Biochem. 2006, 38, 1482-1487. [CrossRef]

88. Vejan, P.; Abdullah, R.; Khadiran, T.; Ismail, S.; Nasrulhaq Boyce, A. Role of plant growth promoting rhizobacteria in agricultural sustainability-A review. Molecules 2016, 21, 573. [CrossRef] [PubMed]

89. Cavagnaro, T.R. The role of arbuscular mycorrhizas in improving plant zinc nutrition under low soil zinc concentrations: A review. Plant Soil 2008, 304, 315-325. [CrossRef]

90. Pearson, J.; Rengel, Z. Distribution and remobilization of Zn and Mn during grain development in wheat. J. Exp. Bot. 1994, 45, 1829-1835. [CrossRef]

91. Ozturk, L.; Yazici, M.A.; Yucel, C.; Torun, A.; Cekic, C.; Bagci, A.; Ozkan, H.; Braun, H.J.; Sayers, Z.; Cakmak, I. Concentration and localization of zinc during seed development and germination in wheat. Physiol. Plant. 2006, 128, 144-152. [CrossRef]

92. Malesh, A.A.; Mengistu, D.K.; Aberra, D.A. 2016. Linking agriculture with health through genetic and agronomic biofortification. Agric. Sci. 2016, 7, 295-307.

93. Haslett, B.S.; Reid, R.J.; Rengel, Z. Zinc Mobility in Wheat: Uptake and Distribution of Zinc Applied to Leaves or Roots. Ann. Bot. 2001, 87, 379-386. [CrossRef]

94. Karim, R.; Zhang, Y.-Q.; Zhao, R.-R.; Chen, X.-P.; Zhang, F.-S.; Zou, C.-Q. Alleviation of drought stress in winter wheat by late foliar application of zinc, boron, and manganese. J. Plant Nutr. Soil Sci. 2012, 175, 142-151. [CrossRef]

95. Cakmak, I. Tansley Review No. 111: Possible roles of zinc in protecting plant cells from damage by reactive oxygen species. New Phytol. 2000, 146, 185-205. [CrossRef] [PubMed]

96. Yilmaz, A.; Ekiz, H.; Gültekin, I.; Torun, B.; Barut, H.; Karanlik, S.; Cakmak, I. Effect of seed zinc content on grain yield and zinc concentration of wheat grown in zinc-deficient calcareous soils. J. Plant Nutr. 1998, 21, 2257-2264. [CrossRef]

97. Harris, D.; Rashid, A.; Miraj, G.; Arif, M.; Yunas, M. 'On-farm' seed priming with zinc in chickpea and wheat in Pakistan. Plant Soil 2008, 306, 3-10. [CrossRef]

98. Cakmak, I. Zinc Fertilizer Strategy for Improving Yield. Fluid J. 2012, 20, 4-7.

99. Gao, X.; Zou, C.; Fan, X.; Zhang, F.; Hoffland, E. From Flooded to Aerobic Conditions in Rice Cultivation: Consequences for Zinc Uptake. Plant Soil 2006, 280, 41-47. [CrossRef]

100. Kutman, U.B.; Yildiz, B.; Cakmak, I. Effect of nitrogen on uptake, remobilization and partitioning of zinc and iron throughout the development of durum wheat. Plant Soil 2011, 342, 149-164. [CrossRef]

101. Manzeke, M.G.; Mtambanengwe, F.; Watts, M.J.; Broadley, M.R.; Murray, L.R.; Mapfumo, P. Nitrogen effect on zinc bio-fortification of maize and cowpea in Zimbabwean smallholder farms. Agron. J. 2020, 112, 2256-2274. [CrossRef]

102. Yang, Z.; Zheng, S.; Hu, A. Zinc nutrition and metabolism of plants as influenced by supply of phosphorus and zinc. Pedosphere 1999, 9, 265-274.

103. Joshi, A.K.; Crossa, J.; Arun, B.; Chand, R.; Trethowan, R.; Vargas, M.; Ortiz-Monasterio, I. Genotype $\times$ environment interaction for zinc and iron concentration of wheat grain in eastern Gangetic plains of India. Field Crops Res. 2010, 116, 268-277. [CrossRef]

104. Mousavi, S.R.; Galavi, M.; Rezaei, M. The interaction of zinc with other elements in plants: A review. Int. J. Agric. Crop Sci. 2012, 4, 1881-1884.

105. Ghasemi-Fasaei, R.; Ronaghi, A. Interaction of Iron with Copper, Zinc, and Manganese in Wheat as Affected by Iron and Manganese in a Calcareous Soil. J. Plant Nutr. 2008, 31, 839-848. [CrossRef]

106. Rajaie, M.; Ejraie, A.K.; Owliaie, H.R.; Tavakoli, A.R. Effect of zinc and boron interaction on growth and mineral composition of lemon seedlings in a calcareous soil. Int. J. Plant Prod. 2012, 3, 39-50.

107. Malewar, G.U.; Kate, S.D.; Waikar, S.L.; Ismail, S. Interaction effects of zinc and boron on yield, nutrient uptake and quality of mustard (Brassica juncea L.) on a typic haplustert. J. Indian Soc. Soil Sci. 2001, 49, 763-765. 
108. Kurdi, F.; Doner, H.E. Zinc and copper sorption and interaction in soils. Soil Sci. Soc. Am. J. 1983, 47, 873-876. [CrossRef]

109. Buerkert, A.; Haake, C.; Ruckwied, M.; Marschner, H. Phosphorus application affects the nutritional quality of millet grain in the Sahel. Field Crops Res. 1998, 57, 223-235. [CrossRef]

110. Egli, I.; Davidsson, L.; Zeder, C.; Walczyk, T.; Hurrell, R. Dephytinization of a Complementary Food Based on Wheat and Soy Increases Zinc, but Not Copper, Apparent Absorption in Adults. J. Nutr. 2004, 134, 1077-1080. [CrossRef] [PubMed]

111. Hotz, C.; Gibson, R.S. Traditional food-processing and preparation practices to enhance the bioavailability of micronutrients in plant-based diets. J. Nutr. 2007, 137, 1097-1100. [CrossRef] [PubMed]

112. Gibson, R.S. Zinc: The missing link in combating micronutrient malnutrition in developing countries. Proc. Nutr. Soc. 2006, 65, 51-60. [CrossRef] [PubMed]

113. Welch, R.M. Importance of seed mineral nutrient reserves in crop growth and development. In Mineral Nutrition of Crops: Fundamental Mechanisms and Implications; Food Products Press: New York, NY, USA, 1999; pp. 205-226.

114. Braun, H.J. Prospects of turkey's wheat industry, Breeding and Biotechnology. In Hububat Sempozyum; Ekiz, H., Ed.; International Winter Cereal Research Center: Konya, Turkey, 1999; pp. 1-744.

115. White, P.J.; Broadley, M. Biofortification of crops with seven mineral elements often lacking in human diets-Iron, zinc, copper, calcium, magnesium, selenium and iodine. New Phytol. 2009, 182, 49-84. [CrossRef] [PubMed]

116. Davis, D.R. Declining Fruit and Vegetable Nutrient Composition: What Is the Evidence? HortScience 2009, 44, 15-19. [CrossRef]

117. Garvin, D.F.; Welch, R.M.; Finley, J.W. Historical shifts in the seed mineral micronutrient concentration of US hard red winter wheat germplasm. J. Sci. Food Agric. 2006, 86, 2213-2220. [CrossRef]

118. White, P.J.; Broadley, M. Physiological Limits to Zinc Biofortification of Edible Crops. Front. Plant Sci. 2011, 2, 80. [CrossRef] [PubMed]

119. Graham, R.D.; Welch, R.M.; Bouis, H. Addressing micronutrient malnutrition through enhancing the nutritional quality of staple foods: Principles, perspectives and knowledge gaps. Adv. Agron. 2001, 70, 77-142.

120. Urbano, G.; Lopez-Jurado, M.; Aranda, P.; Vidal-Valverde, C.; Tenorio, E.; Porres, J. The role of phytic acid in legumes: Antinutrient or beneficial function? J. Physiol. Biochem. 2000, 56, 283-294. [CrossRef] [PubMed]

121. Gemede, H.F.; Ratta, N. Antinutritional factors in plant foods: Potential health benefits and adverse effects. Int. J. Nutr. Food Sci. 2014, 3, 284-289. [CrossRef]

122. Nissar, J.; Ahad, T.; Naik, H.R.; Hussain, S.Z. A review phytic acid: As antinutrient or nutraceutical. J. Pharmacogn. Phytochem. 2017, 6, 1554-1560.

123. Guttieri, M.J.; Peterson, K.M.; Souza, E.J. Agronomic Performance of Low Phytic Acid Wheat. Crop Sci. 2006, 46, 2623-2629. [CrossRef]

124. Oltmans, S.E.; Fehr, W.R.; Welke, G.A.; Raboy, V.; Peterson, K.L. Agronomic and Seed Traits of Soybean Lines with Low-Phytate Phosphorus. Crop Sci. 2005, 45, 593-598. [CrossRef]

125. Schachtman, D.; Barker, S.J. Molecular approaches for increasing the micronutrient density in edible portions of food crops. Field Crops Res. 1999, 60, 81-92. [CrossRef]

126. Eide, D.J. Zinc transporters and the cellular trafficking of zinc. Biochim. Biophys. Acta Bioenerg. 2006, 1763, 711-722. [CrossRef] [PubMed]

127. Ramesh, S.A.; Choimes, S.; Schachtman, D. Over-expression of an Arabidopsis zinc transporter in Hordeum vulgare increases short term zinc uptake after zinc deprivation and seed zinc content. Plant Mol. Biol. 2004, 54, 373-385. [CrossRef] [PubMed]

128. Alloway, B.J. Zinc in Soils and Crop Nutrition; IZA Publications; International Zinc Association: Brussels, Belgium, $2004 ;$ pp. 1-116.

129. White, J.G.; Zasoski, R.J. Mapping soil micronutrients. Field Crops Res. 1999, 60, 11-26. [CrossRef]

130. Darnton-Hill, I.; Webb, P.; Harvey, P.W.; Hunt, J.M.; Dalmiya, N.; Chopra, M.; Ball, M.J.; Bloem, M.W.; De Benoist, B. Micronutrient deficiencies and gender: Social and economic costs. Am. J. Clin. Nutr. 2005, 81, 1198S-1205S. [CrossRef] [PubMed]

131. Wang, Y.-H.; Zou, C.-Q.; Mirza, Z.; Li, H.; Zhang, Z.-Z.; Li, D.-P.; Xu, C.-L.; Zhou, X.-B.; Shi, X.-J.; Xie, D.-T.; et al. Cost of agronomic biofortification of wheat with zinc in China. Agron. Sustain. Dev. 2016, 36, 44. [CrossRef] 